\title{
Penguatan Kapasitas Softskill Guru dalam Upaya Peningkatan Etos Belajar Peserta Didik Pada Masa Pandemi Covid-19
}

\author{
Muhamad Ridwan Effendi ${ }^{1}$, Suci Nurpratiwi ${ }^{2}$, Sari Narulita ${ }^{3}$, \\ Dziyaning Farihani Tsaqila ${ }^{4}$, Muh. Nurhidayat ${ }^{5}$
}

\author{
Program Studi Pendidikan Agama Islam, Universitas Negeri Jakarta Indonesia \\ muhamadridwan@unj.ac.id ${ }^{1}{ }_{\text {sucinurpratiwi@unj.ac.id }}{ }^{2}{ }_{2}{\text { sarinarulita@unj.ac.id }{ }^{3}}^{3}$
}

DOI: doi.org/10.52593/svs.01 .2.01

Naskah diterima: 14 Juli 2021, direvisi: 20 Juli 2021, disetujui: 27 Juli 2021

\begin{tabular}{l}
\hline Abstract \\
\hline Keywords: \\
Learning Ethos, \\
Softskill, Media, Hot \\
Potatoes
\end{tabular}

Abstrak

Kata kunci:

Etos Belajar, Softskil,

Media, Hot Potatoes
The low learning ethic of the participants in the learning process who was brave throughout the Covid-19 pandemic was shown by the attitude of students who did not appreciate the learning process, even they had fun in their world (such as playing games, streaming Youtube, sleeping, travelling) without a teacher. Who is explaining the material, No, this problem is also experienced by teachers at the Nurul Huda Islamic boarding school, Bekasi, where they develop their capacity as teachers in an active, innovative, creative, fun, happy and meaningful (Paikem Gembrot) learning process and increase the learning ethos of students through the use of learning media. Based on this, the community service activity of the community partnership program (PPM PkM) provides soft skills support for teachers through learning media development activities through 1) training and assistance in developing Hot Potatoes learning media for teachers to provide soft skills strengthening in its efforts to improve student's learning ethos; (2) implementing mentoring for teachers to find out their understanding of the material presented; (3) provide a forum for teachers to develop learning models and approaches that can support the improvement of students' learning ethos.

Rendahnya etos belajar peserta didik dalam proses pembelajaran daring sepanjang pandemi Covid-19 ini salah satunya ditunjukkan dengan adanya sikap peserta didik yang kurang menghargai proses belajar, bahkan mereka asyik dengan dunianya sendiri (seperti, bermain game, streaming Youtube, tidur, jalan-jalan) tanpa menghiraukan guru yang sedang menjelaskan materi saat permbelajaran berlangsung. Tak terkecuali, masalah ini juga dialami oleh guru-guru di pondok pesantren Nurul Huda, Bekasi, di mana mereka dituntut untuk mengembangkan kapasitasnya sebagai guru dalam proses pembelajaran yang aktif, inovatif, kreatif, menyenangkan, gembira dan berbobot (Paikem Gembrot) guna mesntimulus pembelajaran dan peningkatan etos belajar peserta didik melalui penggunaan media pembelajaran di masa pandemic Covid-19 ini. Berdasarkan hal tersebut, kegiatan pengbdian kepada masyarakat program kemitraan masyarakat (PPM PkM) ini memberikan penguatan softskill guru melalui kegiatan pengembangan media pembelajaran melalui 1) pelatihan dan pendampingan dalam pengembangan media pembelajaran Hot Potatoes bagi guru guna memberikan penguatan softskill dalam upayanya meningkatan etos belajar peserta didik; (2) mengimplementasikan pendampingan kepada guru guna mengetahui pemahaman mereka terkait materi yang disampaikan; (3) memberikan wadah bagi guru untuk mengembangkan kreativitas model dan pendekatan pembelajaran yang dapat mendukung pada peningkatan etos belajar peserta didik. 


\section{PENDAHULUAN}

Sudah hampir setahun sejak tanggal 13 April 2020 Presiden Republik Indonesia, Ir. Joko Widodo melalui Keputusan Presiden (Keppres) Nomor: 12 tahun 2020 secara resmi menetapkan wabah penyakit Corona Virus Diseases 2019 (Selanjutnya disebut Covid-19) sebagai bencana nasional (Ihsanudin 2020). Berdasarkan hal tersebut, telah mendorong Pemerintah Indonesia pun mengambil kebijakan yang bertujuan untuk memutus rantai penularan pandemi Covid-19 dengan mengimbau masyarakat untuk mengurangi segala aktivitas di luar rumah demi menekan penyebaran virus Covid-19 di Indonesia. Salah satunya adalah penerapan kebijakan Social Distancing atau umumnya masyarakat menyebut sebagai physical distancing, di mana warga harus menjalankan seluruh aktivitas di rumah, seperti bekerja, belajar, termasuk dalam melaksanakan ibadah.

Adanya penerapan kebijakan physical distancing ini jelas sangat berdampak terhadap sektor pendidikan tak terkecuali di Pondok Pesantren Nurul Huda, Kecamatan Setu Kabupaten Bekasi. Pandemi Covid-19 ini telah menuntut pemerintah Indonesia untuk mengambil keputusan yang pahit dengan menutup lembaga pendidikan untuk mengurangi kontak orang-orang secara masif dan untuk menyelamatkan hidup atau tetap harus membuka lembaga pendidikan dalam rangka survive. Dengan demikian, kegiatan belajar mengajar pun terpaksa dilaksanakan dalam jarak jauh. Akan tetapi, dari kebijakan ini juga banyak pihak terutama Pondok Pesantren Nurul Huda, Kecamatan Setu Kabupaten Bekasi yang belum siap sepenuhnya untuk melaksankan pembelajaran melalui jarak jauh atau yang dikenal dengan sebutan online/ daring (dalam jaringan).

Sampai saat ini (baca; 22 Februari 2021), pandemi covid-19 di Indonesia masih berlangsung, hal ini didasarkan dari informasi tren perkembangan kasus Covid-19 yang tidak kunjung turun grafiknya yakni untuk kaus positif 1.288.8333, sembuh 1.096.9994, dan kasus meninggal 34.691 (Covid-19 2021). Hal ini tentunya berdampak terhadap Kegiatan belajar mengajar yang dilaksanakan oleh guru dan peserta didik Pondok Pesantren Nurul Huda, Kecamatan Setu Kabupaten Bekasi di rumah masing-masing atau dalam jaringan (daring) masih dianggap belum efektif, hal ini ditandai dengan terbatasnya kemampuan masyarakat, keterbatasan sarana prasarana, jaringan internet, dan biaya bahkan pada etos belajar pesersta didik yang menurun.

Sebagai lembaga pendidikan yang berada dekat dengan pusat perkotaan, diperkuat pula dengan kota Bekasi sebagai daerah penyangga ibukota negara yakni Jakarta. Arus perkembangan zaman yang modern ini telah memberikan pengaruh besar terhadap arus perubahan sosial yang berdampak pada lingkungan di pondok pesantren Nurul Huda terutama dalam perkembangan IPTEK yang dapat menimbulkan dampak positif dan negatifnya bagi guru dan peserta didik Pondok Pesantren Nurul Huda, Kecamatan Setu Kabupaten Bekasi. Kemajuan IPTEK yang tidak dibarengi dengan penguatan kualitas proses pembelaran menjadi faktor utama yang menyebabkan peserta didik terdampak buruk dan memiliki etos belajar yang rendah

Secara faktual, beberapa kasus yang terjadi di Pondok Pesantren Nurul Huda, Kecamatan Setu Kabupaten Bekasi rendahnya etos belajar peserta didik dalam pembelajaran daring ini di antaranya muncul sikap peserta didik yang kurang menghargai proses belajar, bahkan dmereka asyik dengan dunianya sendiri (seperti, bermain game, streaming youtube, tidur, jalan-jalan) tanpa menghiraukan guru yang sedang menjelaskan materi. Ini salah satu turunya etos belajar yang diakibatkan karena peserta didik terlalu berat dalam menanggung 
beban. Entah beban moril maupun materil atau juga beban keluarga, karena bisa jadi keluarganya kurang begitu mendukung dalam mengikuti pembelajaran. Hal seperti ini tentunya yang mengakibatkan peserta didik di Pondok Pesantren Nurul Huda, Kecamatan Setu Kabupaten Bekasi tertinggal dalam pembelajarannya.

Kasus tersebut jelas sangat berdampak pada etos belajar peserta didik, sehingga dibutuhkan model, metode atau bahkan media pembelajaran yang dapat mendorong meningkatknya etos belajar peserta didik dalam proses pembelajaran selama masa pandemi Covid-19 yang dilakukan oleh guru (assatidz) di Pondok Pesantren Nurul Huda, Kecamatan Setu Kabupaten Bekasi tanpa bertentangan dengan semangat perkembangan zaman dengan dukungan faktor lingkungan pendidikan yang ada (Muhamad Ridwan Effendi, Rudi M. Barnansyah 2019).

Di tengah perkembangan zaman dewasa ini, keluarga tentunya tidak bisa secara mutlak memiliki banyak ruang dan waktu dalam membimbing proses pembelajaran anaknya selama di rumah,(Aida Noer Aini, Muhamad Ridwan Effendi 2021) semisal karena berbagai faktor kesibukan atau tingkat kognisinya, oleh sebab itu terkadang orangtua membantu sekemampuannya atau bahkan acuh tak acuh dalam memberikan bimbingan kepada anakknya selama pandemi Covid-19 ini.

Untuk itu, kegiatan pengbdian kepada masyarakat program kemitraan masyarakat (PPM PkM) yang dilaksanakan di Pondok Pesantren Nurul Huda, Kecamatan Setu Kabupaten Bekasi ini diharapkan dapat memberikan kualitas proses pembelajaran dalam upaya meningkatkan etos belajar peserta didik melalui penguatan softskill guru dalam pengembangan media pembelajaran dengan platform Hot Potatoes. Penguatan Softskill guru Pondok Pesantren Nurul Huda, Kecamatan Setu Kabupaten Bekasi ini pernting untuk dilakukan, mengingat beberapa faktor di antara menurunnya etos belajar peserta didik di Pondok Pesantren Nurul Huda, Kecamatan Setu Kabupaten Bekasi disebabkan karena kurangnya variasi penggunaan media pembelajaran daring yang dilakukan oleh guru selama masa pandemi Covid-19 ini.

Pemilihan kegiatan pengabdian dengan topik penguatan softskill guru dalam upaya meningkatkan etos belajar peserta didik pada masa pandemi Covid-19 di Pondok Pesantren Nurul Huda, Kecamatan Setu Kabupaten Bekasi merupakan suatu upaya refleksi sekaligus mendorong munculnya kreativitas, inovasi dan kualitas keterampilan serta pengalaman guru dala melaksanakan proses pembelajaran.

Mengacu pada analisis situasi di atas, permasalahan mitra dapat diuraikan sebagai berikut: Pertama, pondok pesantren Modern Nurul Huda sebagai lembaga pendidikan yang diketahui belum pernah ada kegiatan penguatan softskill bagi guru dalam bentuk pelatihan dan pendampingan pengembangan media pembelajaran Hot Potatoes dalam proses pembelajaran terhadap peserta didiknya. Kedua, mengetahui keadaan peserta didik yang ada di pondok pesantren Modern Nurul Huda mengalami masa pada titik kejenuhan, apatis dan cenderung etos belajarnya menurun sebagai dampak pandemi Covid-19 yang mengharuskan kegiatan pembelajaran dilakukan secara daring (pembelajaran jarak jauh). Ketiga, adanya berbagai dampak yang ditimbulkan dari adanya penurunan etos belajar tersebut, terlihat pada perubahan sikap belajar peserta didik yang tidak menghargai guru ketika menjelaskan materi saat proses pembelajaran, selain itu sikap atau perilaku peserta didik lebih memilih bermain game, jalan-jalan, bahkan tidur daripada memperhatikan proses pembelajaran. 
Selanjutnya, penulis melakukan penetapan isu masalah utama yang akan dijadikan kegiatan PkM dengan menggunakan metode APKL (Aktual, Problematik, Kekhlayakan, Layak) sebagai teknik survey kepada 7 orang guru pondok pesantren Nurul Huda Bekasi. Aktual artinya isu benar-benar terjadi dan sedang hangat dibicarakan. Problematik artinya sebuah isu memiliki dimensi masalah yang kompleks sehingga harus segera dicarikan solusi permasalahannya. Kekhalayakan artinya isu tersebut menyangkut hajat hidup orang banyak. Kelayakan artinya isu yang diangkat masuk akal dan realistis untuk dipecahkan masalahnya.

Tabel 1. Penetapan Isu/ Masalah dengan Metode APKL

\begin{tabular}{|c|l|c|c|c|c|c|}
\hline \multirow{2}{*}{ No } & \multicolumn{1}{|c|}{ Isu } & \multicolumn{3}{|c|}{ Kriteria } & \multirow{2}{*}{ Jumlah } \\
\cline { 3 - 6 }$(1)$ & \multicolumn{1}{|c|}{ (2) } & P & K & L & \\
\hline 1 & $\begin{array}{l}\text { Pondok pesantren Modern Nurul Huda } \\
\text { belum pernah ada kegiatan penguatan } \\
\text { softskill bagi guru dalam bentuk pelatihan } \\
\text { dan pendampingan pengembangan media } \\
\text { pembelajaran Hot Potatoes }\end{array}$ & 5 & 7 & 6 & 4 & 22 \\
\hline 2 & $\begin{array}{l}\text { Peserta didik di pondok pesantren Modern } \\
\text { Nurul Huda mengalami kejenuhan, apatis } \\
\text { dan cenderung etos belajarnya menurun } \\
\text { sebagai dampak pembelajaran daring selama } \\
\text { pandemi Covid-19 }\end{array}$ & 3 & 4 & 4 & 3 & 14 \\
\hline \multirow{2}{*}{3} & $\begin{array}{l}\text { Perubahan sikap belajar peserta didik } \\
\text { ditunjukkan dengan sikap tidak menghargai } \\
\text { guru ketika menjelaskan materi dan lebih } \\
\text { memilih bermain game, mematikan video } \\
\text { saat pembelajran virtual dan tidur-tiduran } \\
\text { saat proses pembelajaran. }\end{array}$ & 5 & 4 & 4 & 5 & 19 \\
\hline
\end{tabular}

Keterangan: A:Aktual P:Problematik K:Kekhalayakan $\quad$ L:Layak

Adapun tujuan dari kegiatan Pengabdian kepada Masyarakat Program Kemitraan Masyarakat (PPM PkM) ini adalah: Pertama, memberikan pelatihan dan pendampingan dalam pengembangan media pembelajaran Hot Potatoes, bagi guru guna memberikan penguatan softskill dala upayanya meningkatan etos belajar peserta didik; Kedua, berkontribusi dalam mengimplementasikan pendampingan kepada guru guna mengetahui pemahaman mereka terkait materi yang disampaikan; Ketiga, memberikan wadah bagi guru untuk mengembangkan kreativitas model dan pendekatan pembelajaran yang dapat mendukung pada peningkatan etos belajar peserta didik; Keempat, target luaran yang diharapkan dalam kegiatan ini adalah sedapat mungkin memberikan nilai manfaat dan membangun daya nalar kritis guru dalam pembelajaran terhadap peserta didik.

\section{METODE}

Berdasarkan uraian fakta masalah di atas, program kegiatan Pengabdian kepada Masyarakat Program Kemitraan Masyarakat (PPM PkM) ini terbagi menjadi 5 (Lima) tahap 
yakni observasi, persiapaan, pelaksanaan dan pendampingan. Adapun tahapan tersebut, di antaranya: Pertama, Observasi, pada tahap ini dilakukan dengan cara mendatangi untuk mengobservasi lokasi pelatihan sebelum menyusun tahapan persiapan pelatihan. Dengan diadakannya observasi ini diharapkan bisa mengetahui lebih awal bagaimana keadaan atau kondisi mitra baik peserta didik dan guru yang ada di lembaga tersebut; Kedua, Persiapan, pada tahap ini dilakukan analisa APKL (Aktual-Problematis-Khalayak-Layak) untuk memperoleh data awal yang dijadikan fokus kegiatan dari hasil observasi di lapangan. Dengan melihat keadaan atau kondisi tempat pengabdian maka dapat disusun tahapan persiapan sebelum melaksanakan pengabdian kepada masyarakat tersebut seperti mengecek sarana prasarana yang dapat mendukung pelaksanaan pengabdian dan sosialisasi terhadap pihak terkait yakni pimpinan dan guru-guru pondok pesantren Nurul Huda, Bekasi. Diantaranya adalah penetapan masalah yang dihadapi guru, peserta didik, pengurusan ijin pelaksanaan, penyusunan proposal dan pengajuan proposal kegiatan. Pengecekan komputer dan menyimpan aplikasi Hot Potatoes di komputer yang akan digunakan termasuk dalam tahap ini sehingga pada hari pelaksanaan Pelatihan, fasilitas pelatihan telah siap pakai; Ketiga, Pelaksanaan, pada tahap pelaksanaan kegiatan dilaksanakan dengan metode pelatihan dan pendampingan dalam pengembangan media pembelajaran Hot Potatoes, bagi guru guna memberikan penguatan softskill dala upayanya meningkatan etos belajar peserta didik. Karena ini merupakan pelatihan yang berkaitan dengan pengoperasian komputer, maka diharapkan pelatihan dilaksanakan di Laboratorium Komputer atau ruangan ada fasilitas notebook/ laptop sehingga guru dapat langsung praktek dalam menggunakan aplikasi Hot Potatoes dan dapat melakukan diskusi pada saat setelah pemberian materi dilaksanakan; dan Keempat, Pendampingan, pada tahap ini bertujuan untuk mengevaluasi pemahaman peserta kegiatan terkait materi pelatihan yang diajarkan, oleh karena itu perlu adanya pendampingan. Tim dibantu oleh beberapa mahasiswa program studi Pendidikan Agama Islam yang telah dibekali pengetahuan terkait penggunaan aplikasi Hot Potatoes sehingga memudahkan Tim dalam mempraktekkan materi yang telah diterima; Kelima, Evaluasi, pada kegiatan evaluasi ini dapat memberikan masukan lebih intens untuk kepentingan jangka panjang agar program kegiatan Pengabdian kepada Masyarakat Program Kemitraan Masyrakat (PPM PkM) ini dapat lebih berkualitas dan memastikan keberhasilan kegiatan dengan indikator kesiapan menerima materi, peran aktif, keterampilan bertindak kritis dalam melakukan pengembangan media, model dan pendekatan pembelajaran terhadap peserta didik.

\section{HASIL DAN PEMBAHASAN}

\section{Kekhalayakan dan Realisasi Pelaksanaan Kegiatan}

Berdasarkan informasi yang diperoleh terkait permasalahan mitra seperti yang diuraikan sebelumnya, tim pengabdian ingin membantu memberikan solusi terhadap permasalahan yang dihadapi mitra. Yaitu, rendahnya etos belajar peserta didik sebagai akibat dari proses pembelajaran yang berlangsung secara daring di masa pandemic covid-19 ini masih dinilai monoton, pasif, belum efektif dan tidak menstimulus peserta didik terlebih menunjukkan adanya perubahan sikap belajar ke arah yang cenderung negatif.

Proses belajar yang dilakukan secara daring tersebut, perlu didorong dengan penguatan keterampilan guru dalam pengembangan media pembelajaran. Hal ini perlu dilakukan agar interaksi yang dilakukan antara guru dan peserta didik dapat berjalan 
sebagaimana yang diharapkan yaitu, terciptanya suasana belajar PAIKEM GEMBROT (Pembelajaran yang Aktif, Inovatif, Kreatif, Menyenangkan, Gembira dan Berbobot). Tentunya Teknologi dan informasi yang saat ini berembang dapat membantu guru dalam mengembangkan media pembelajaran agar dalam prosesnya berlangsung sesuai dengan kaidah PAIKEM GEMBROT tadi. Salah satu media teknologi dan informasi yang dapat dikembangkan dalam pembelajaran tersebut adalah Hot Potatoes.

Hot Potatoes merupakan tool untuk membuat Bank Soal, program ini terdiri dari 6 (enam) program yang dapat digunakan untuk membuat materi pengajaran secara interaktif berbasis web. Software ini dibuat oleh universitas vicotria di Canada. Hot Potatoes juga dapat digunakan secara bebas oleh banyak lembaga seperti lembaga pendidikan untuk berinteraksi antara guru dan peserta didik. Hot Potatoes sangat mendukung pembelajaran kolaboratif dan mendukung proses sharing pengetahuan melalui jejaring sosial (Huang dkk, 2010) yang tidak menggantikan proses belajar mengajar di sekolah, namun juga dapat menjadi alternatif media pembelajaran yang tidak hanya terpaku pada ruang kelas dan waktu.

Tim pengabdian mencoba menawarkan solusi dengan menerapkan media dengan menggunakan aplikasi Hot Potatoes. Untuk mengakses aplikasi Hot Potatoes maka diperlukan perangkat komputer untuk menyediakan fitur-fitur sharing pengetahuan, penugasan, tes dan juga bertindak sebagai jejaring sosial untuk interaksi guru dan peserta didik. Berdasarkan hal tersebut dapat memberikan penguatan softskill guru dalam mengembangkan kapasitasnya di bidang media pembelajaran guna meningkatkan etos belajar peserta didik dalam pembelajaran daring selama pandemic covid-19 bagi guru-guru pondok pesantren Nurul Huda Bekasi.

Kegiatan ini dilaksankan di pondok pesantren Nurul Huda Bekasi yang dilaksanakan dan bertepatan dengan berakhirnya tahun ajaran sebelumnya dan dalam rangka mempersiapkan kegiatan belajar mengajar di tahun ajara baru. Seluruh peserta merupakan guru yang pada proses belajar mengajar. Adapun daftar peserta kegiatan ini secara rinci dilampirkan pada bagian terpisah dari artikel ini.

Sesuai dengan tahapan pelaksanaan kegiatan ini, kegiatan ini diawali dengan pengenalan tentang Hot Potatoes. Pengenalan ini digunakan untuk membantu para guru memahami aplikasi dan penggunaannya dalam proses pembelajaran. Adapun kegiatan ini dilaksanakan di aula pondok pesantren Nurul Huda Bekasi.

Masing-masing peserta menggunakan 1 unit laptop/ komputer selama pelaksanaan praktik berlangsung dan diberikan modul untuk memberikan kemudahan dalam proses praktikum. Kegiatan ini juga dilaksanakan dalam 1 (satu) hari dengan durasi pelatihan adalah \pm 4 (empat) jam, terdiri dari: 40 menit pengenalan aplikasi Hot Potatoes, 180 menit untuk pelatihan dengan dua sesi, dan 20 menit untuk evaluasi keseluruhan materi.

Adapun pembagian materi pelatihannya adalah sebagai berikut: 1) Sesi 1 untuk materi Hot Potatoes, pembuatan catatan, share materi, penugasan dan penilaian kemudian dilakukan evaluasi; dan 2) Sesi 2 untuk materi Hot Potatoes, perbaikan, dan penilaian kemudian dilakukan uji coba.

Luaran yang dapat dihasilkanari kegiatan ini adalah kemampuan peserta dalam menggunakan media pembelajaran dengan aplikasi Hot Potatoes. Kemampuan pemahaman peserta juga diperoleh berdasarkan hasil evaluasi yang dilakukan terhadap para peserta yaitu guru. Evaluasi dilakukan dua cara, yaitu melalui kuesioner dan melalui praktik di tempat. Evaluasi praktik dilakukan dengan simulasi kelas maya, di mana peserta yang terdiri dari 
para guru tersebut saling memberikan penilaian bersadarkan hasil uji coba. Diberikan ketentuan masing-masing peserta untuk menjalankan fitur pada aplikasi Hot Potatoes. Berikut agenda yang direncanakan ketika kegiatan berlangsung.

Tabel 2. Agenda kegiatan

\begin{tabular}{|c|c|c|c|c|}
\hline No & Tahapan & Materi/ Kegiatan & Metode & Waktu \\
\hline \multirow{4}{*}{1} & Pembukaan & $\begin{array}{ll}\text { - } & \text { Sambutan Pimpinan } \\
& \text { Pondok Pesantren } \\
\text { - } & \text { Sambutan Kaprodi S1- } \\
& \text { PAI }\end{array}$ & Ceramah & $09.00-09.15$ \\
\hline & Penjelasan Materi & $\begin{array}{l}\text { Memberikan materi tentang } \\
\text { ragam media pembelajaran }\end{array}$ & $\begin{array}{c}\text { Diskusi, tanya } \\
\text { jawab, ceramah }\end{array}$ & $09.15-09.35$ \\
\hline & $\begin{array}{l}\text { Pengenalan } \\
\text { Aplikasi Hot } \\
\text { Potatoes }\end{array}$ & $\begin{array}{l}\text { Memberikan materi dan } \\
\text { fitur-fitur pada Hot Potatoes }\end{array}$ & Diskusi & $09.35-09.50$ \\
\hline & Free Test & $\begin{array}{l}\text { Evaluasi awal terhadap } \\
\text { materi }\end{array}$ & Diskusi & $09.50-10.00$ \\
\hline \multirow{7}{*}{2} & \multirow{7}{*}{$\begin{array}{l}\text { Pelatihan Aplikasi } \\
\text { Hot Potatoes (Sesi } \\
\text { 1) }\end{array}$} & $\begin{array}{l}\text { Menjelaskan fitur-fitur } \mathrm{Hot} \\
\text { Potatoes }\end{array}$ & $\begin{array}{c}\text { Diskusi, tanya } \\
\text { jawab, ceramah }\end{array}$ & $10.00-10.15$ \\
\hline & & $\begin{array}{l}\text { Mengunduh dan } \\
\text { menginstall aplikasi Hot } \\
\text { Potatoes }\end{array}$ & \multirow{6}{*}{$\begin{array}{l}\text { Praktik, tanya } \\
\text { jawab, ceramah }\end{array}$} & \multirow{6}{*}{$10.15-11.30$} \\
\hline & & $\begin{array}{l}\text { Menggunakan fitur create } \\
\text { menu }\end{array}$ & & \\
\hline & & $\begin{array}{l}\text { Menambahkan data materi } \\
\text { dan soal pada menu }\end{array}$ & & \\
\hline & & Membuat assignment & & \\
\hline & & $\begin{array}{l}\text { Membagikan kode dan } \\
\text { materi Hot Potatoes }\end{array}$ & & \\
\hline & & Evaluasi & & \\
\hline \multirow[t]{3}{*}{3} & $\begin{array}{l}\text { Pelatihan Aplikasi } \\
\text { Hot Potatoes (Sesi } \\
\text { 1) }\end{array}$ & $\begin{array}{l}\text { Mengedit aplikasi yang } \\
\text { telah dibuat sesuai hasil } \\
\text { review dan penilaian teman } \\
\text { sejawat dan narasumber }\end{array}$ & \multirow[t]{2}{*}{$\begin{array}{l}\text { Praktik, tanya } \\
\text { jawab, ceramah }\end{array}$} & \multirow[t]{2}{*}{$11.30-12.00$} \\
\hline & & Uji coba & & \\
\hline & Post Test & $\begin{array}{l}\text { Evaluasi keseluruhan } \\
\text { materi }\end{array}$ & $\begin{array}{l}\text { Diskusi dan } \\
\text { Mengisi } \\
\text { kuisioner }\end{array}$ & $12.00-12.30$ \\
\hline
\end{tabular}

Evaluasi keberhasilan kegiatan pelatihan dan pendampingan ini dilakukan setelah masing-masing sesi pelatihan dan pada akhir kegiatan. Setiap sesi pelatihan akan dilakukan evaluasi kemudian dilanjutkan evaluasi materi secara keseluruhan di akhir kegiatan. Indikator keberhasilan dari kegiatan ini dilihat dari respon positif dari para peserta melalui evaluasi yang telah diberikan serta proses diskusi yang dilakukan selama kegiatan berlangsung. Evaluasi kegiatan juga dilakukan berupa pembagian kuesioner yang wajib diisi 
oleh peserta terkait dengan kegiatan yang telah mereka ikuti dan pengembangan media Hot Potatotes yang telah dibuat pada proses belajar mengajar.

Melalui pelatihan dan pendampingan ini, diharapkan guru pondok pesantren Nurul Huda Bekasi dapat memanfaatkan dan menerapkan teknologi informasi sebagai media untuk mencerdaskan peserta didik. Sehingga guru tidak terlalu terbebani dengan kegiatan belajar mengajar dan peserta didik dapat kreatif memanfaatkan media pembelajaran berbasis aplikasi tersebut. Selain itu guru dapat melakukan proses belajar mengajar yang tidak terpaku pada ruang kelas maya yang mainstream dan cenderung monoton dan menyedot quota internet.

\section{Kelayakan Tim Pengabdian}

Kegiatan pengabdian yang telah ditetapkan ini tentunya memerlukan beberapa jenis kepakaran atau keahlian. Jenis keahlian yang dibutuhkan yaitu: (1) bidang teknologi informasi, (2) sistem informasi dan (3) bidang pendidikan. Sehingga untuk keberhasilan program pengabdian yang dilaksanakan, maka tim pengabdian ini terdiri dari beberapa dosen dengan bidang keahlian yang dibutuhkan serta dibantu oleh beberapa teknisi. Tim pelaksana pengabdian terdiri dari 3 dosen.

Pengalaman dari tim pelaksana kegiatan ini dalam hal pengabdian kepada masyarakat dan pengajar mata kuliah, dalam kurun waktu 5 tahun terakhir, seperti tersebut di dalam Tabel 3 berikut ini.

Tabel 3. Pengalaman dalam bidang PKM dan IT

\begin{tabular}{|l|l|l|l|}
\hline \multicolumn{1}{|c|}{ Nama } & Tahun & \multicolumn{1}{|c|}{ Nama Kegiatan } & \multicolumn{1}{c|}{ Tempat } \\
\hline $\begin{array}{l}\text { Muhamad Ridwan Effendi, } \\
\text { M.Ud. }\end{array}$ & 2020 & $\begin{array}{l}\text { Pembinaan Perilaku Altruistik } \\
\text { dan Keberagamaan Santri }\end{array}$ & $\begin{array}{l}\text { Ponpes Nurul Huda } \\
\text { Bekas }\end{array}$ \\
\hline Suci Nurpratiwi, M.Pd. & 2020 & $\begin{array}{l}\text { Pelatihan Pengembangan } \\
\text { Media Flipped Calssroom }\end{array}$ & $\begin{array}{l}\text { Ponpes Nurul Huda } \\
\text { Bekas }\end{array}$ \\
\hline Sari Narulita, M.Si. & 2020 & $\begin{array}{l}\text { Pengembangan Bahan Ajar } \\
\text { Menggunakan Media } \\
\text { Pembelajaran Huda }\end{array}$ & $\begin{array}{l}\text { Ponpes Nurul Huda } \\
\text { Bekas }\end{array}$ \\
\hline Dziyaning Farihani Tsaqila & - & Teknisi IT & - \\
\hline Muh. Nurhidayat & - & Manajemen Informasi & - \\
\hline
\end{tabular}

Adapun untuk melaksanakan kegiatan pengabdian kepada masyarakat ini, jenis kepakaran dan pembagian tugas adalah sebagaimana tercantum dalam Tabel 4 berikut ini.

Tabel 4. Jenis Kepakaran dan Uraian Tugas

\begin{tabular}{|c|c|c|}
\hline Pelaksana & Uraian Tugas & Kepakaran \\
\hline $\begin{array}{l}\text { Muhamad Ridwan Effendi, } \\
\text { M.Ud. }\end{array}$ & $\begin{array}{l}\text { 1. Penyusunan Modul; } \\
\text { 2. }\end{array}$ & Media IT \\
\hline Suci Nurpratiwi, M.Pd. & $\begin{array}{ll}\text { 1. } & \text { Penyusunan Modul; } \\
\text { 2. } & \text { Pembuatan Media }\end{array}$ & $\begin{array}{l}\text { Ponpes Nurul Huda } \\
\text { Bekas }\end{array}$ \\
\hline Sari Narulita, M.Si. & $\begin{array}{ll}\text { 1. } & \text { Manajemen Kegiatan } \\
\text { 2. } & \text { Telaah Modul }\end{array}$ & $\begin{array}{l}\text { Ponpes Nurul Huda } \\
\text { Bekas }\end{array}$ \\
\hline Dziyaning Farihani Tsaqila & 1. Asisten Pendamping & IT \\
\hline
\end{tabular}




\begin{tabular}{|c|c|c|}
\hline & 2. Teknisi IT & \\
\hline Muh. Nurhidayat & $\begin{array}{ll}\text { 1. } & \text { Humas dan Publikasi } \\
\text { 2. } & \text { Teknisi IT }\end{array}$ & IT \\
\hline
\end{tabular}

\section{Kelayakan Peserta}

Adapun Peserta yang mengikuti kegiatan PkM ini sejumlah 22 orang guru yang berasal dari pondok pesantren Nurul Huda Bekasi. Seluruh peserta merupakan guru yang mengajar mata pelajaran bidang studi yang tidak sering menggunakan media pembelajaran dalam proses belajar mengajar. Seperti guru rumpun mata pelajaran Pendidikan Agama yaitu Aqidah Akhlak, SKI, Fiqh dan Quran Hadits.

\section{Analisis Hasil Pengabdian}

Analisis hasil ini diperoleh berdasarkan evaluasi-evaluasi dari tiap sesi yang diberikan, berikut analisa hasil dari evaluasi di tiap sesi:

Tabel 5. Hasil Free Test

\begin{tabular}{|c|c|c|c|c|}
\hline Prosentase & $\begin{array}{c}\text { Kepuasan } \\
\text { terhadap } \\
\text { media } \\
\text { pembelajaran }\end{array}$ & $\begin{array}{c}\text { Relative } \\
\text { Advantage } \\
\text { Media }\end{array}$ & $\begin{array}{c}\text { Familiarisasi } \\
\text { Media Hot } \\
\text { Potatoes }\end{array}$ & $\begin{array}{c}\text { Keefektifan } \\
\text { Media Hot } \\
\text { Potatoes }\end{array}$ \\
\hline Ya & 22,7 & 41 & 13,63 & 41 \\
\hline Tidak & 50 & 54,5 & 81,8 & 50 \\
\hline Mungkin & 31,8 & 4,5 & 4,5 & 9 \\
\hline Orang & \multicolumn{5}{|l}{} \\
\hline Ya & 5 & 9 & 3 & 9 \\
\hline Tidak & 11 & 12 & 18 & 11 \\
\hline Mungkin & 7 & 1 & 1 & 2 \\
\hline
\end{tabular}

Kuesioner/Free test pertama diberikan setelah pemaparan terkait materi $H t$ Postatoes. Pada kuesioner ini $50 \%$ peserta atau 11 peserta tidak puas terhadap media pembelajaran yang pernah dipelajari peserta serta meragukan keefektifan penggunaan media pembelajaran lain. Dari 22 peserta, 81.8\% belum pernah mendengar tentang Hot Potatoes namun hanya 13,63\% yang pernah mendengar/ mengetahui Hot Potatoes.

Tabel 6. Hasil Post Test

\begin{tabular}{|l|c|c|c|}
\hline \multicolumn{1}{|c|}{ Prosentase } & $\begin{array}{c}\text { Mengetahui } \\
\text { Fitur-fitur } \\
\text { Hot Potatoes }\end{array}$ & $\begin{array}{c}\text { Menggunakan } \\
\text { Fitur-fitur Hot } \\
\text { Potatoes }\end{array}$ & $\begin{array}{c}\text { Akan } \\
\text { mengajarkan } \\
\text { Hot Potaotes } \text { ke } \\
\text { Peserta Didik }\end{array}$ \\
\hline Sudah, Sudah, Ya & 86 & 72,7 & 68 \\
\hline Ragu, Ragu, Ragu & 13,6 & 27 & 32 \\
\hline $\begin{array}{l}\text { Belum, Belum, } \\
\text { Tidak }\end{array}$ & 0 & 0 & 0 \\
\hline Orang & & & \\
\hline
\end{tabular}




\begin{tabular}{|l|c|c|c|}
\hline Sudah, Sudah, Ya & 19 & 16 & 15 \\
\hline Ragu, Ragu, Ragu & 3 & 6 & 7 \\
\hline $\begin{array}{l}\text { Belum, Belum, } \\
\text { Tidak }\end{array}$ & 0 & 0 & 0 \\
\hline
\end{tabular}

Post Test terkait pelatihan Hot Potatoes ini sejumlah 86\% peserta atau 19 orang peserta paham dan mengetahui dan cara menggunakan fitur-fitur di Hot Potatoes. $68 \%$ atau 15 peserta akan mengajarkan Hot Potatoes ke peserta didiknya.

Tabel 7. Kuisioner Materi Keseluruhan

\begin{tabular}{|l|c|c|c|}
\hline \multicolumn{1}{|c|}{ Prosentase } & $\begin{array}{c}\text { Hot Potatoes } \\
\text { akan } \\
\text { membantu } \\
\text { KBM }\end{array}$ & $\begin{array}{c}\text { Akan } \\
\text { Menggunakan } \\
\text { Hot Potatoes }\end{array}$ & $\begin{array}{c}\text { Akan } \\
\text { mengenalkan } \\
\text { Hot Potaotes ke } \\
\text { Peserta Didik }\end{array}$ \\
\hline Sudah, Sudah, Ya & 90 & 77 & 77 \\
\hline Ragu, Ragu, Ragu & 40 & 22 & 22 \\
\hline $\begin{array}{l}\text { Belum, Belum, } \\
\text { Tidak }\end{array}$ & 0 & 0 & 0 \\
\hline Orang & 20 & 17 & 17 \\
\hline Sudah, Sudah, Ya & 9 & 5 & 5 \\
\hline Ragu, Ragu, Ragu & 0 & 0 & 0 \\
\hline $\begin{array}{l}\text { Belum, Belum, } \\
\text { Tidak }\end{array}$ & \multicolumn{2}{|l}{} \\
\hline
\end{tabular}

Kuesioner ketiga ini berisi tentang keseluruhan pelatihan dan tanggapan tentang media Hot Potatoes. Berdasarkan kuesioner yang sama dan diisi kepada peserta guru-guru pondok pesantren Nurul Huda Bekasi, dapat dirangkum bahwa peserta memiliki beberapa tanggapan mengenai Hot Potatoes seperti table 7 di atas.

\section{Evaluasi Kegiatan Pengabdian}

Evaluasi kegiatan ini dilakukan melalui 2 (dua) cara, selain melalui kuesioner manual yaitu free tes dan post tes, evaluasi juga dilakukan secara langsung pada aplikasi Hot Potaties dengan melihat di aplikasi Hot Potatoes apakah peserta sudah dapat menggunakan fitur dan memunculkannya di kelas maya yang sudah disediakan. Sebagian besar peserta dapat langsung mencoba dan menggunakan fitur catatan, penugasan, polling, kuis dan fitur lainnya. Beberapa peserta sudah dapat memasukan materi dan soal serta memberikan nilai dipenugasan yang telah diisi. Hasil penggunaan fitur-fitur oleh peserta di Hot Potaotes telah di screenshot dan dilampirkan pada laporan.

Selain itu, dalam kegiatan pengabdian ini bagi peserta diharapkan luaran kegiatan yang dicapai yaitu berupa peningkatan pemahaman dan penguatan softskill peserta terkait media aplikasi Hot Potatoes dan penggunaan fitur-fitur aplikasi Hot Potatoes. Dilihat dari hasil evaluasi tentang pemahaman media Hot Potatoes melalui kuesioner dan evaluasi yang di peroleh dari mempraktekan penggunaan fitur-fitur tersebut. Serta bagi tim pengabdian, luaran yang dicapai adalah draf modul yang dapat digunakan untuk pelatihan Hot Potates 
selanjtunya atau menjadi rujukan modul pelatihan penggunaan media pembelajaran Hot Potatos berikutnya.

\section{KESIMPULAN}

Tenaga pendidik atau guru di Pondok Pesantren Nurul Huda Bekasi sebagai penerima manfaat setelah mendapatkan pelatihan peningkatan penggunaan media pembelajaran dengan aplikasi Hot Potatoes. Guru Pondok Pesantren Nurul Huda Bekasi mengetahui manfaat Hot Potatoes pada proses belajar mengajar dan dapat menggunakan fitur-fitur yang disediakan sebagai media pembelajaran yang tidak hanya terpaku pada media pembelajaran digital lain. Peserta dapat memanfaatkan teknologi informasi sebagai media untuk mencerdaskan peserta didik serta tidak terlalu terbebani dengan kegiatan belajar mengajar dan peserta didik dapat dengan kreatif memanfaatkan media pembelajaran sebagai pendukung proses belajar mengajar. Berdasarkan evaluasi kuisioner, seluruh peserta sepakat bahwa Hot Potatoes akan membantu proses belajar mengajar dan 68\% akan mengenalkan Hot Potatoes.

Selain itu juga, diperlukan adanya perubahan pola mengajar di sekolah dengan pemanfaatan teknologi informasi sehingga guru dan peserta didik masih dapat melakukan proses belajar mengajar yang Paikem Gembrot. Selain itu perlu pendampingan ketika mengenalkan media pembelajaran Hot potatoes ke peserta didik agar lebih mudah dipahami dan peserta didik dapat dikenalkan pada teknologi informasi yang bermanfaat bagi pendidian.

\section{UCAPAN TERIMA KASIH}

Penulis mengucapkan terima kasih kepada pimpinan dan para guru pondok pesantren Nurul Huda Bekasi yang telah menyediakan waktu, tempat, tenaga, dan pikirannya untuk ikut serta dalam kegiatan pengabdian ini. Pun juga kepada segenap keluarga besar sivitas akademika program studi Pendidikan Agama Islam Fakultas Ilmu Sosial dan tim panitia dan tim pengabdian yang turut mensukseskan baik dari konsep dan teknis penyelenggaraan kegiatan. Serta kepada Universitas Negeri Jakarta yang telah memberi dukungan finansial terhadap penyelenggaan pengabdian ini.

\section{DAFTAR PUSTAKA}

Aida Noer Aini, Muhamad Ridwan Effendi, Euis Nurjanah. 2021. "Strategi Menanamkan Nilai Nilai Akhlak Melalui Integrasi Pendidikan." Paedagogie 2(34-47).

Covid-19, Satgas. 2021. "Data Sebaran Kasus Covid-19 Di Indonesia." Covid19.Go.Id. Retrieved (https://covid19.go.id/).

Huang. J. J. S. , Yang , S.J. H., Huang, Y-M., dan Hasio ,I. Y. T., 2010, Social Learning Networks: Build Mobile LEarning Networks Based on Collaborative Services, Educational Techonology \& Society, 13 (3), 78 - 92.

Ihsanudin. 2020. "Presiden Jokowi Teken Keppres Tetapkan Wabah Covid-19 Bencana Nasional." KOMPAS.Com. Retrieved (https://nasional.kompas.com/read/2020/04/13/18101841/presiden-jokowi-tekenkeppres-tetapkan-wabah-covid-19-bencana-nasional).

Muhamad Ridwan Effendi, Rudi M. Barnansyah, Suci Nurpratiwi. 2019. Model Pendidikan Inklusif Pondok Pesantren. Jakarta: Laboratorium PAI FIS UNJ. 
SIVITAS, Vol. 1. No. 2 Juli 2021, 41-51

Nurpratiwi, Muhamad Ridwan Effendi dan Suci. 2021. "Hubungan Keberagamaan Dan Perilaku Altruistik Mahasiswa." Al-Afkar 4(1):83-97.

Ucu Cahyana, Iwan Sugihartono, Dkk. 2021. Panduan Penelitian Dan Pengabdian Kepada Masyarakat Universitas Negeri Jakarta. Jakarta: LPPM UNJ. 